Original Paper

\title{
滤過性に着目した凝集結晶晶析条件の検討
}

\section{Crystallization Conditions of Crystal Agglomerates Suitable for Filtration Separation}

\author{
椋田 隆司, ${ }^{\mathrm{a}}$ 下条 芳敬, ${ }^{\mathrm{a}}$ 後藤 邦彰 ${ }^{\mathrm{b}}$ \\ Takashi Mukuta, Yoshitaka Shimojo, Kuniaki Gotoh
}

Received 5 April 2006 ; Accepted 21 June 2006

Although crystallization process is optimized mainly with respect to the physicochemical properties, the mechanical properties such as the strength of crystal particles are the important factors in the industrial process because the crystallization usually follows the filtration process and the filtration time occupies relatively a long time in the whole processing time. In this study, the crystallization process of a sulfate which forms spherical agglomerate of primary crystal particles has been studied with particular attention to the effect of the operating conditions of crystallization on the filtation characteristics of crystal agglomerates.

The filtration characteristics were evaluated by the specific resistance calculated from Darcy's equation through the filtration experiments carried out under constant pressure drop. The compression ratio is also measured with a tapping method. It was found that the specific resistance has almost no correlation with the compression ratio, suggesting that the compression ratio is an inadequate parameter for the evaluation of the filtration characteristics. The specific resistance of agglomerated crystal is higher at a lower crystallization temperature and a higher mixing speed during crystallization. However, the amount of seed particles has no effect on the specific resistance.

The centrifugal filtration time under optimized conditions were compared with the filtration time under the condition employed in an industrial process. It was confirmed that the filtration time of the tested sulfate crystals can be reduced to a half by optimizing of the operating conditions of crystallization.

Keywords : Crystallization, Filtration, Agglomerate crystal, Darcy's law

\section{1. 粕言}

一般に，医薬品原薬などでは，媒体から有用物質を 分離する方法として，晶析操作により粒子状物質を得 た後, 滤過操作が多く適用される。このようなプロセ スでは, 晶析操作が製品の純度, 結晶形状, 色調, 粒 径分布などの物理化学的特性を制御する重要な単位操 作となっている。一方，この晶析操作は製品だけでな く，後に続く濾過操作に対しても大きな影響を与え

a アステラス製薬（株）合成技術研究所

（テ318-0001 茨城県高萩市赤浜160-2） TEL 0293-23-4197

Process Chemistry Labs. Astellas Pharma Inc.

(160-2, Akahama, Takahagi, Ibaraki 318-0001, Japan) $b$ 岡山大学大学院自然科学研究科

（テ700-8530 岡山県岡山市津島中 3-1-1）TEL 086-251-8084

The Graduate School of Natural Science and Technology, Okayama University

(3-1-1, Tsushimanaka, Okayama 700-8530, Japan)
る。すなわち，滤過操作での操作性が悪い粒子，例え ば，長い濾過時間や滤過による粒子形状変化が起こる 粒子では，滤過後に設定した通りの物質化学的特性が 得られないばかりでなく，生産性や作業性にも大きく 影響を与える。実際に，遠心分離機などを用いる滤過 操作では，遠心時の付加圧力により結晶が破砕される と滤過時に形成されるケーキ層での圧力損失が増大 し, 滤過時間の増加を招く。したがって, 滤過圧力で も破砕されにくい結晶を得ることも，晶析プロセスで は重要となる。

単結晶を生成する晶析操作では, 晶析操作で結晶を ゆっくり成長させ，粒径の大きな単結晶を得ること で, 滤過時間を短くすることが可能である。しかし，

Fig. 1 に一例を示すような凝集結晶を生成する場合に は，析出した一次結晶粒子同士が衝突し，次いで粒子 間に架橋が析出し，一次粒子が凝結して凝集結晶が形 


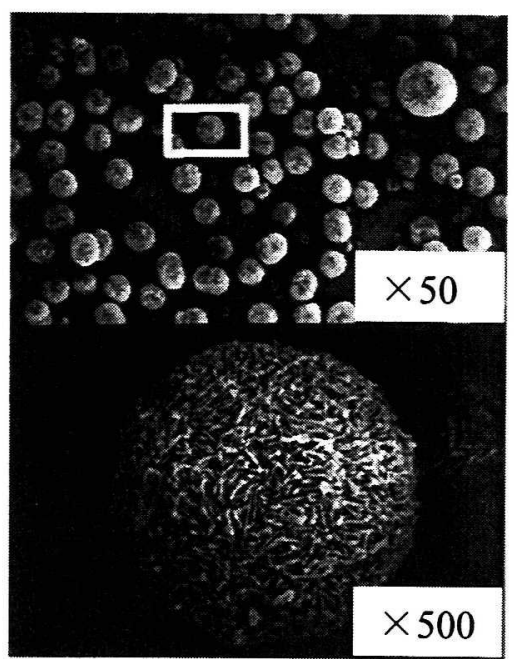

Fig. 1 Example of agglomerated crystal (Spherical agglomerate crystal of Wincef)

成されるので, 生成する結晶特性のプロセス操作変数 依存性は複雑であり, 濾過時間を短くするための操作 条件を設定するのは困難である。例えば，晶析過程で の衝突に影響を及ばす操作条件としては擋拌速度や種 晶量が考えられ，一方，一次粒子の凝結には溶質の濃 度や晶析温度が影響すると考えられる。このような過 程を経る凝集晶の晶析プロセスについて, 得られる結 晶の流動性や圧縮性などの粉体特性に着目した報告1) はあるが, 濾過特性に影響する結晶の強度に着目して 操作条件を検討した例はほとんどない。

晶析で生成した粒子の操作性に着目した晶析操作条 件に対する検討として，筆者らは，Fig. 2 に示した構 造を持つ硫酸塩であるアステラス製薬（株）の医薬 品・注射用セファロスポリン剤ウィンセフ，(-)-5amino-2- [[(6R, 7R) - 7- [(Z) - 2- (2-amino-4thia zolyl) -2- (methoxyimino) acetamido] -2carboxy-8-oxo-5-thia-1-azabicyclo [4.2.0] oct2-en-3-yl] methyl] -1- (2-hydroxyethyl) - $1 H^{-}$ pyrazolium hydroxide inner salt monosulfate $\sigma$ 晶析プロセスについて, 注射用バイアル容器への充壃

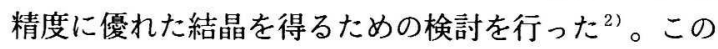
ウィンセフの製造では，まず，母核構造を持つ中間体 之側鎖酸との縮合反応によりウィンセフの化学構造を 構築する。その後, 合成樹脂を用いた精製により不純 物を除去し, 活性部の濃縮を行った後, 貧溶媒である イソプロピルアルコール (以下 IPA と略す) を添加し て結晶（以下精 WIN と称す）を得ている。この精<smiles></smiles>

(-)-5-amino-2-[[(6R,7R)-7-[(Z)-2-(2-amino -4 - thiazolyl)-2-( methoxyimino) acetamido $]-2$ carboxy-8-oxo-5- thia-1-azabicyclo [4.2.0] oct2 -en-3-yl] methyl]-1-(2- hydroxyethyl)- $1 H$ pyrazolium hydroxide inner salt monosulfate

Fig. 2 Chemical structure of Wincef

WIN を用いて無菌化再晶析工程によりウィンセフの

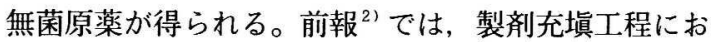
ける充媜精度に優れたウィンセフ結晶, すなわち, 緻 密な球状凝集結晶を析出させることを目的として, 晶 析プロセスの操作条件である過飽和度, 晶析温度, 擋 拌数について検討を行った。

無菌化再晶析工程前の精 WIN は, 医薬品原薬であ るウィンセフと同様に球状凝集結晶であるが, $12 \mathrm{~m}^{3}$ の商業スケールにおいて，その濾過操作に約 10 時間 かかり，プロセス上で大きな䦗題となっている。この 濾過操作では遠心分離機が用いられており, 約 0.35 $\mathrm{MPa}$ の圧力が結晶ケーク層に付加される。このため, この付加厈力により凝集結晶の破砕等が起こり, ケー ク層の圧密化などにより濾過性が低下すると考えら れる。

そこで, 本研究では, 精 WIN 結晶粒子を対象とし て，圧力による圧密化が起きにくい，すなわち，圧縮 性の小さな緻密な結晶を得ることを目的として, 晶析 プロセスの各操作変数 (晶析温度, 擋拌速度, 種晶 量）が結晶粒子性状に与える影響を実験的に検討し た。その検討において, 精 WIN 結晶粒子の性状とし て, 粒子径分布など物理的特性に加え, 実際の濾過プ ロセスを模した加圧条件下において溶媒の透過流量を 測定し，Darcy の式より計算されるケーク比抵抗を 用いて濾過特性を評価した。

\section{2. 実験装置および方法}

\section{1 晶析実験}

晶析実験には, 内径 $D$ と擋拌翼であるファウド ラー翼径 $d$ の比を, 商業生産スケールでの晶析槽の比 と同じ $d / D=0.7$ として幾何相似にした，容量 0.02 $\mathrm{m}^{3}$ のガラス製の晶析装置を用いた。実験操作は Fig. 3 に示したように，精 WIN 水溶液に硫酸を添加して 硫酸塩とした後, 貧溶媒であるIPA を添加し, 所定 


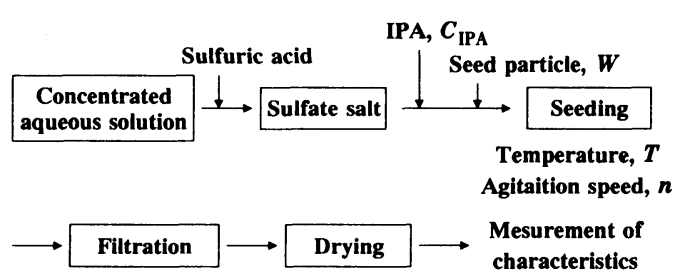

Fig. 3 Process flow diagram of Wincef

の質量割合 $W$ で種晶を添加した後，収量を上げるた めに所定温度 $T$ まで泠却した。この晶析装置の操作 変数である晶析温度 $T$ は, ウィンセフが熱的に不安 定であることから，分解を抑制するためにできるだ け低温で操作することが望ましい。一方で，低温に し過ぎると，結晶化せずにオイルとして析出するの で，安定して結晶が析出する温度範囲に設定した。こ の安定して結晶析出する温度は, 晶析前の精 WIN 水 溶液濃度 $C_{0}$ に依存するため, 詳細な温度については 後述する。また，もう一つの装置操作である翼回転 速度 $n$ は, 商業生産スケールの晶析槽擋拌速度範囲 （28rpm〜113rpm）と，精 WIN 水溶液単位体積当た りの所要動力が等しくなるように，28～48rpm の範 囲とした。これら本実験範囲内では, 得られた結晶 は，Fig. 1 に示したような球状凝集晶であった。な お，IPA 添加後に溶液は過飽和溶液となっている が，種晶を添加しないと結晶が析出しないことから， IPA 涯加速度は晶析プロセスに影響を与えないと判 断した。

この晶析操作中，種晶を添加後の一定時間ごとに晶 析液をサンプリングし，フィルターを用いて滤過後， 高速液体クロマトグラフ法で定量することで晶析液 中の上澄み溶液濃度 $C$ の経時変化を測定し, 析出率 $\left(1-C / C_{0}\right)$ の経時変化を求めた。

また，晶析終了後に濾過して得られた湿潤結晶は， 棚式乾燥機を用いて約 $313 \mathrm{~K}$ で 15 時間以上真空乾燥 した。得られた粉体について，滤過ケーク層の圧縮性 を評価する指標として，タップ法による比容を求め た。このタップ法では乾燥した結晶 $5 \mathrm{~g}$ を測定管に仕 込み, 約 $5 \mathrm{~cm}$ の高さから 100 回タップした前後の容 積から緩め比容および固め比容を求め, 緩め比容と 固め比容の差を緩め比容で除して圧縮率 $R_{\mathrm{c}}$ を求め た。また，篩過法による粒度分布測定から平均粒子径 $D_{\mathrm{p} 50}$ を求めた。

\section{2 滤過特性の評価}

上述の晶析後, 乾燥して得られた精 WIN を粒子濃 度 $73 \mathrm{~kg} / \mathrm{m}^{3}$ で IPA 㫫濁し, 円筒状の滤過器（濾過面
積 $6.6 \mathrm{~cm}^{2}$, 焼結金網）に仕込んだのち, 滤過圧力 0.2 MPa で濾過した。ケーク層表面に IPA が残る状態で 滤液の出口を閉じた後, 滤過により形成したケーキ層 を圧力 $0.2 \mathrm{MPa}$ の空気で 10 分間圧密し, その後, 王 力 $0.1 \mathrm{MPa}$ で IPA を透過させ, 透過液量を測定した。 なお，IPA 透過前には，压密後のケーク層のリバウ ンは生じていないことを確認した。また，精WIN は IPA にはほとんど溶解しないため, 再溶解の影響は 無視できると考えた。そこで，透過液量から Darcy の式 (Eq. (1)) を用い，透過比抵抗 $\alpha$ を求めた。

$$
q=P /(\alpha \cdot \omega \cdot \mu)
$$

このようにして求めた比抵抗 $\alpha$ は，王密状態でのヶー クの抵抗であるので，遠心分離機を用いる滤過プロセ スで形成される正密状態での比抵抗に相当すると考 え，ここでは，この比抵抗を濾過プロセス中での結晶 粒子の滤過特性を表わす指標とした。なお，比抵抗に は滤材の透過抵抗も含まれるが，結晶を含まないIPA のみの滤過時間は結晶を含む場合に比へ十分短かった ことから，濾材抵抗の影響は無視できると考えた。

また, 比抵抗の検討の結果得られた最適操作条件で の結晶粒子については，小型遠心式滤過機を用いて， 商業生産での遠心力と同じ付加圧力における条件で滤 過を行い，従来の晶析条件で得られた結晶粒子と滤過 性を比較した。すなわち，乾燥前の晶析液を， 0.35 $\mathrm{MPa}$ の遠心力で滤過し，压縮したケーク層を形成後， 晶析液をフィードし，時間ごとの滤過液量を測定した。 滤液量が計測されなくなった時間を滤過時間 $t_{\mathrm{f}}$ とし, その時間でのケーク層の比容および厚さを測定した。

\section{3. 結果と考察}

\section{1 晶析温度の影繁}

Fig. 4 に，異なる晶析温度で得られた精 WIN 結晶 粒子の透過比抵抗 $\alpha$ を示す。また，図に示した実験結

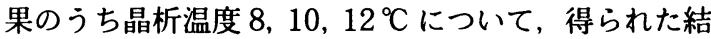
晶粒子の特性を測定した結果を Table 1 に示す。図か ら分かるように, 晶析温度が高いほど比抵抗が大きく なった。このとき，比容も大きくなることから，結晶 の凝集性の低下，すなわち，疎な凝集結晶の生成によ り, 透過試験時の圧密で粒子の破砕が起きたため, 比 抵抗が大きくなったと考えられる。

晶析温度 $8,10,12^{\circ} \mathrm{C}$ につて, 析出率の経時変化 を測定した結果を Fig. 5 に示す。晶析温度が低い $8^{\circ} \mathrm{C}$ の場合，晶析時間 0.5 時間までに $10 \%$ 程度まで急激 に上昇し，その後 1 時間程度までは析出量の増加はな 


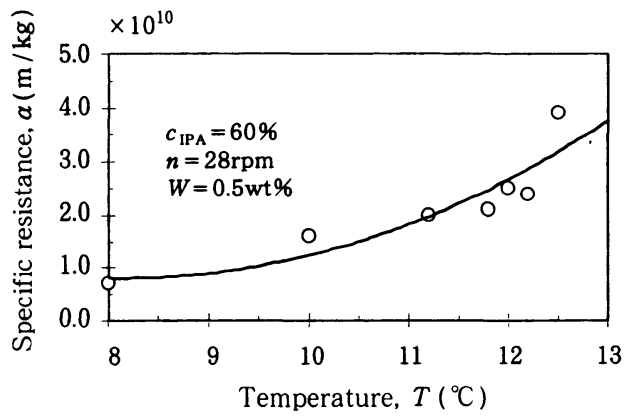

Fig. 4 Effect of temperature on specific resistance

Table 1 Powder characteristics obtained under various temperatures

\begin{tabular}{ccccc}
\hline Temperature, $T$ & $\left({ }^{\circ} \mathrm{C}\right)$ & 8 & 10 & 12 \\
\hline \hline $\begin{array}{c}\text { Volume weight ratio } \\
\text { before tapping }\end{array}$ & $\left(\mathrm{cm}^{3} / \mathrm{g}\right)$ & 2.74 & 3.16 & 3.57 \\
$\begin{array}{c}\text { Volume weight ratio } \\
\text { after tapping }\end{array}$ & $\left(\mathrm{cm}^{3} / \mathrm{g}\right)$ & 2.19 & 2.37 & 2.44 \\
$\begin{array}{c}\text { Compression ratio, } R_{\mathrm{c}} \\
(\%)\end{array}$ & 20.1 & 25.0 & 31.7 \\
$D_{\mathrm{p} 50}$ & $(\mu \mathrm{m})$ & 88 & 102 & 123 \\
\hline & $\left(c_{\mathrm{IPA}}=60 \%, n=28 \mathrm{rpm}, W=0.5 \mathrm{wt} \%\right)$
\end{tabular}

く，1時間経過後から再度析出量が増加している。こ の変化傾向から, 晶析温度 $8^{\circ} \mathrm{C}$ では, 高い過飽和度 のため, 初期に一次粒子が急激に析出し，その後，凝 集が起こり，凝集 1 次粒子間をつなぐ凝結による析出 量増加が起こったものと考えられる。一方, 温度の高

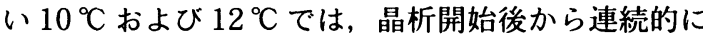
増加しており，一次粒子の析出之凝集，凝結が同時に 進行しているものと予想される。また，急激な析出量 の増加が始まる時間は温度が高い方が早いが，その後 の増加傾向は $8^{\circ} \mathrm{C}$ の 1 時間経過以降の増加傾向とほ ぼ同じである。さらに時間が経過して析出が進み，析 出量 $80 \%$ 以上となると, 析出量は晶析温度に依存し

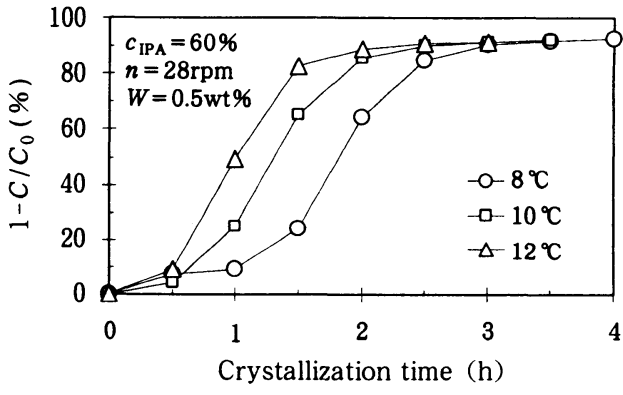

Fig. 5 Change of crystallization ratio with time なくなる。これは，本実験範囲内ではいずれの晶析温 度でも平衡状態まで到達しておらず，析出速度が遅い ために見かけ上温度の影響がなくなったためと考えら れる。この結果から, 晶析温度は特に晶析初期の析出 速度に影響し，緻密な凝集結晶を得るためには，晶析 初期の析出速度を抑制する条件が有効であると予想さ れる。

Fig. 4 からは，さらに低温にすることで滤過性の 改善が期待されるが, IPA 濃度 $60 \%$ という条件下で は $6{ }^{\circ} \mathrm{C}$ 以下で種晶添加前に微細結晶が析出し, 晶析 中にオイル状物が析出し, 安定した晶析操作が困難と なった。そこで，IPA 濃度を $60 \%$ から $50 \%$ とする ことで，過飽和度を低下させて低温での晶析を試み た。得られた結晶粒子の比抵抗を Table 2 に, 晶析操 作中の析出率の経時変化を Fig. 6 に示した。また, 得 られた結晶粒子の特性を Table 2 に合わせて示した。

Table 2 に示したように, IPA 濃度を変えている ので過飽和度は $5{ }^{\circ} \mathrm{C}$ の場合が最も高いが，この過飽 和度の大小によらず, Fig. 4 の結果と同様, 温度が 低いほうが比抵抗は小さい。一方, Table 2 の結果 では，温度が低い方が比容も圧縮率も小さいが, Table 1 の $8^{\circ} \mathrm{C}$ の結果と比較すると, 温度の高い 8 ${ }^{\circ} \mathrm{C}$ での圧縮率は Table 2 の $5{ }^{\circ} \mathrm{C}, 0^{\circ} \mathrm{C}$ よりも小さく,

Table 2 Specific resistance and powder characteristics obtained under various concentration of IPA

\begin{tabular}{ccccc}
\hline Temperature, $T$ & $\left({ }^{\circ} \mathrm{C}\right)$ & 10 & 5 & 0 \\
Concentration of IPA, $c_{\text {IPA }}$ & $(\%)$ & 60 & 55 & 50 \\
Super- saturation ratio, $C / C^{*}$ & $(-)$ & 13.4 & 15.9 & 14.5 \\
\hline Specific resistance, $\alpha$ & $(\mathrm{m} / \mathrm{kg})$ & $1.6 \times 10^{10}$ & $0.4 \times 10^{10}$ & $0.2 \times 10^{10}$ \\
$D_{\mathrm{p} 50}$ & $(\mu \mathrm{m})$ & 102 & 81 & 72 \\
Volume weight ratio before tapping & $\left(\mathrm{cm}^{3} / \mathrm{g}\right)$ & 3.16 & 2.90 & 2.69 \\
Volume weight ratio after tapping & $\left(\mathrm{cm}^{3} / \mathrm{g}\right)$ & 2.37 & 2.20 & 2.07 \\
Compression ratio, $R_{\mathrm{c}}$ & $(\%)$ & 25.0 & 24.1 & 22.9 \\
\hline
\end{tabular}




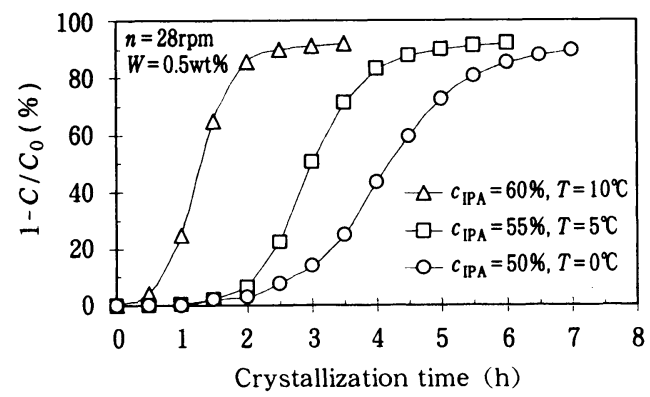

Fig. 6 Change of crystallization ratio under various IPA concentration

$10^{\circ} \mathrm{C}$ と比較した場合と異なる。この比抵抗と圧縮率 の傾向の相違については，後述する。

析出率変化を見ると, 過飽和度の最も高い $5^{\circ} \mathrm{C} よ$ りも $0^{\circ} \mathrm{C}$ の方が晶析初期の結晶析出速度が低く, Fig. 5 と同様, 温度が低いほど結晶析出速度が低くなって いる。このことから, 晶析初期の結晶析出は, 温度に よる過飽和度の違いよりも, 別の温度の要因, 例えば 溶液の粘度変化などに主に依存していると考えられ る。

\section{2 擋挥速度}

一般に，摚拌が強い場合は凝集結晶が破砕され，ま た，弱い場合には一次結晶粒子の衝突頻度の低下によ る凝集阻害が起きることから, 凝集に最適な摚拌速度 があると考えられる。IPA 濃度 $60 \%$, 晶析温度 $8{ }^{\circ} \mathrm{C}$ として, 摚拌回転数を変えた場合の比抵抗の違いを Fig. 7 に示す。晶析温度の影響と比較すると変化は小 さいが, 本実験範囲内においては, 回転数の増加に従 い単調に比抵抗が増加する。

析出率の経時変化 (Fig. 8) をみると, 先の温度の影 響と同様，比抵抗が小さい低回転数の方が晶析初期で の析出速度が小さい。しかし, 結晶粒子の特性を見る と, 晶析温度を下げた場合には比抵抗が小さいほうが

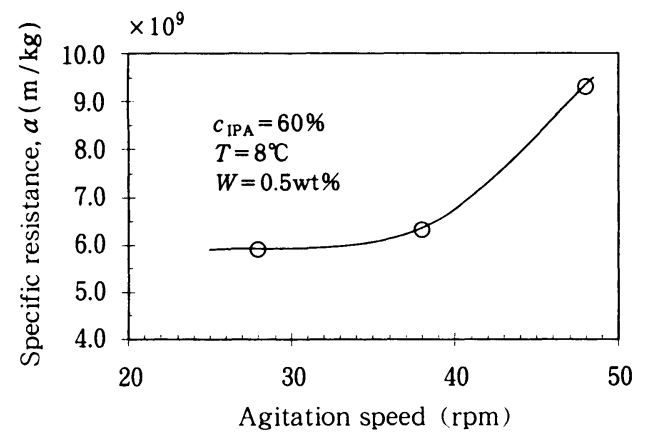

Fig. 7 Effect of agitation speed on specific resistance

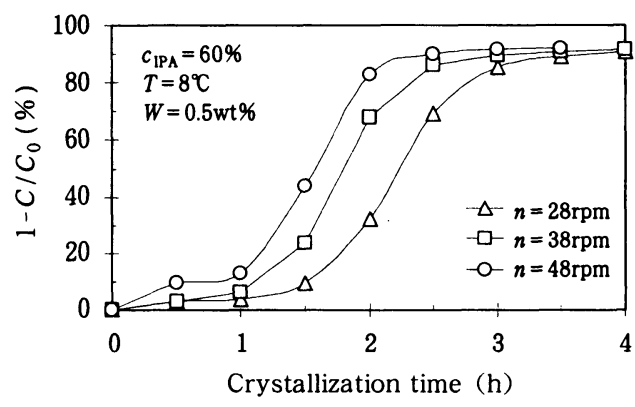

Fig. 8 Change of crystallization ratio with time under various agitation speed

Table 3 Powder characteristics obtained under various agitation speed

\begin{tabular}{ccccc}
\hline Agitation speed, $n$ & $(\mathrm{rpm})$ & 28 & 38 & 48 \\
\hline $\begin{array}{c}\text { Volume weight ratio } \\
\text { before tapping }\end{array}$ & $\left(\mathrm{cm}^{3} / \mathrm{g}\right)$ & 2.76 & 2.67 & 2.66 \\
$\begin{array}{c}\text { Volume weight ratio } \\
\text { after tapping }\end{array}$ & $\left(\mathrm{cm}^{3} / \mathrm{g}\right)$ & 2.17 & 2.15 & 2.2 \\
$\begin{array}{c}\text { Compression ratio, } R_{\mathrm{c}} \\
D_{\mathrm{p} 50}\end{array}$ & $(\mu \mathrm{m})$ & 21.4 & 19.5 & 17.3 \\
& $\left(c_{\text {IPA }}=60 \%, T=8^{\circ} \mathrm{C}, W=0.5 \mathrm{wt} \%\right)$
\end{tabular}

粒子径も圧縮率も小さくなるのに対し，摚拌速度を変 えた場合（Table 3）には，比抵抗の小さい低回転の方 が粒子径も圧縮率も大きい。擋拌回転数が, 衝突頻度 が問題とならない程度に高く，かつ，擋拌により凝集 結晶が破砕すると仮定すると, 強度の低い凝集結晶中 の疎な部分は破砕され, 強度の高い密な部分のみが残 ることから，擋拌速度が高いほうが緻密で強度の高い 凝集結晶ができると考えられる。Table 3 の圧縮率 はこの状況を反映しているものと予想される。原料量 が同じで緻密であるために, 粒子径 $D_{\mathrm{p} 50}$ も回転数が 高いほど小さい。緻密である場合, 温度の影響では比 抵抗が小さくなるが, Fig. 7 では逆に大きくなって いるのは粒子径が小さいことが影響していると考えら れるが,これは後に考察する。

\section{3 種晶}

晶析温度 $8{ }^{\circ} \mathrm{C}$, IPA 濃度 $60 \%$ の条件の下, 種晶量 を変えた場合の比抵抗を Fig. 9 に示す。種晶量を増や すと比抵抗は減少するが， $0.05 w t \%$ から $0.2 w t \%$ に 増加させたときの減少に比へ， $0.2 \mathrm{wt} \%$ から $0.5 \mathrm{wt} \%$ に増加させたときの変化は小さい。また, 得られた結 晶の特性（Table 4）を見ると, 粒子径に大きな変化は ないが，生縮率は $0.2 \mathrm{wt} \%$ と $0.5 \mathrm{wt} \%$ ではほぼ同じ なのに対し，0.05wt％は他に比へてて大きい。圧縮率 が大きい，すなわち，タッピングにより破砕されるな 


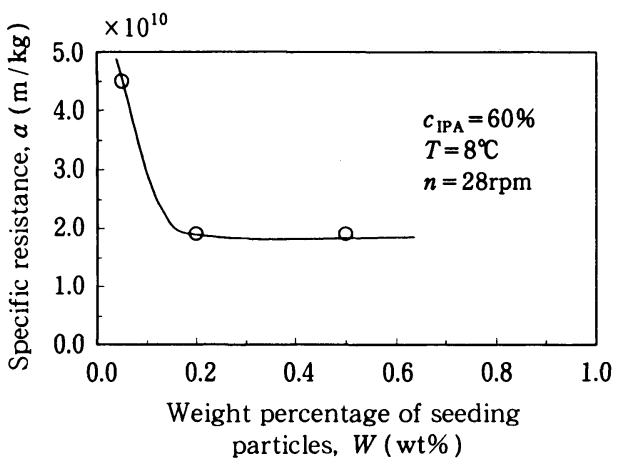

Fig. 9 Effect of amount of seeding particles on specific resistance

Table 4 Powder characteristics obtained under various seeding amount

\begin{tabular}{cllll}
\hline Seeding amount, $W$ & $(\mathrm{wt} \%)$ & 0.05 & 0.20 & 0.50 \\
\hline $\begin{array}{c}\text { Volume weight ratio } \\
\text { before tapping }\end{array}$ & $\left(\mathrm{cm}^{3} / \mathrm{g}\right)$ & 3.02 & 2.94 & 2.86 \\
$\begin{array}{c}\text { Volume weight ratio } \\
\text { after tapping }\end{array}$ & $\left(\mathrm{cm}^{3} / \mathrm{g}\right)$ & 2.21 & 2.22 & 2.15 \\
$\begin{array}{c}\text { Compression ratio, } R_{\mathrm{c}} \\
D_{\mathrm{p} 50}\end{array}$ & $(\%)$ & 26.8 & 24.5 & 24.8 \\
& $\left(c_{\mathrm{IPA}}=60 \%, T=8^{\circ} \mathrm{C}, n=28 \mathrm{rpm}\right)$
\end{tabular}

どで見かけ容積の減少の大きい結晶ほど比抵抗は大き くなるという点で, 晶析温度の影響と類似する。しか し，析出率の時間変化（Fig. 10）では種晶量が少ない ほうが初期の晶析速度は小さく, 晶析速度が小さいほ うが比抵抗は大きくなり, 温度の影響とは反対の傾向 になる。

また，温度の影響において最も比抵抗の小さかった 晶析温度 $0{ }^{\circ} \mathrm{C}$, IPA 濃度 $50 \%$ の条件の下で種晶量を 変えた場合，比抵抗（Fig. 11）は種晶量に依存しない。 一方, 析出率の時間変化 (Fig. 12) は, Fig. 10 と同 様, 種晶量が少ないほうが初期の晶析速度は小さい。

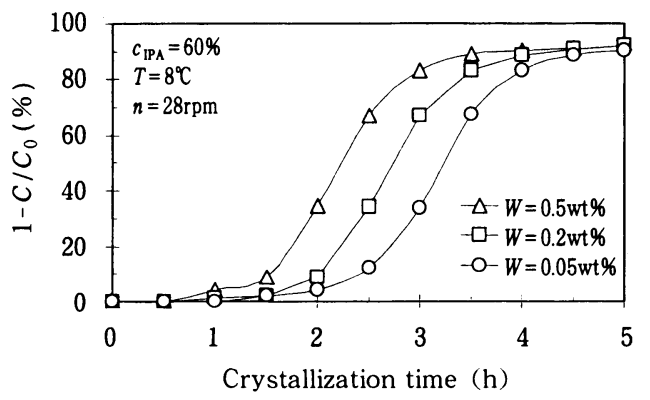

Fig. 10 Change of crystallization ratio under various seeding amount

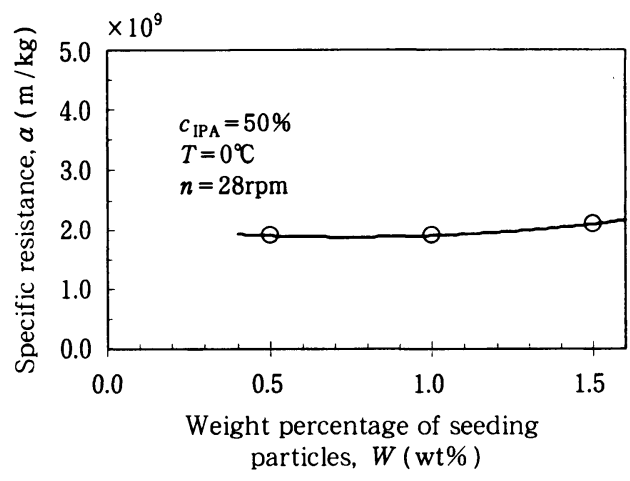

Fig. 11 Effect of amount of seeding particles on the specific resistance

よって, この条件で種晶量を変えた場合には, 析出速 度が変化しているにもかかわらず比抵抗はほとんど変 化しない。また，Table 5 を見ると，得られた結晶の 粒子径はほとんよ゙変化せず, 比容, 圧縮率と共に明確 な変化傾向はなく，ほぼ一定とみなすことができる。

種晶量の影響について, 晶析温度 $8{ }^{\circ} \mathrm{C}, 0^{\circ} \mathrm{C}$ の両方 の結果を合わせてみると, 晶析初期の析出速度は, 種 晶量が多い, すなわち, 種晶の総表面積が大きい方が 大きくなると言える。このことから析出速度は, 種晶 との衝突確率に依存すると予想される。一方, 析出速 度と圧縮率, 比抵抗との間に明確な関連は見られない ことから, 種晶量は, 晶析温度や回転速度などのよう に凝結過程には影響しないと考えられる。晶析温度 8 ${ }^{\circ} \mathrm{C}$, 種晶量 $0.05 \mathrm{wt} \%$ では明確な比抵抗の増加が認め られたのは, 前述の種晶面積が小さいため, 種晶粒子 単位面積当たりの析出量が多くなり, 結晶粒子が集中 したことで疎な構造となったためと考えられる。

ここで，粒子特性として求めた压縮率と粒子径 $D_{\mathrm{p} 50}$ ，比抵抗の関係について考える。Fig. 13 に示し たように，压縮率を粒子径 $D_{\mathrm{p} 50}$ に対してプロットす ると, IPA 濃度を変えて晶析温度を変えた場合を除

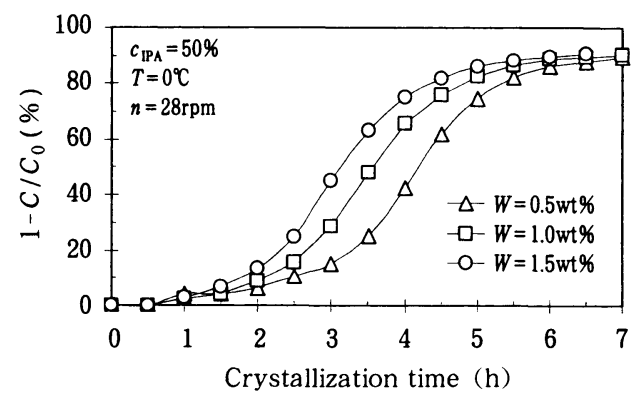

Fig. 12 Change of crystallization ratio under various seeding amount 
Table 5 Powder characteristics obtained under various seeding amount

\begin{tabular}{clccc}
\hline Seeding amount, $W$ & $(\mathrm{wt} \%)$ & 0.5 & 1.0 & 1.5 \\
\hline $\begin{array}{c}\text { Volume weight ratio } \\
\text { before tapping }\end{array}$ & $\left(\mathrm{cm}^{3} / \mathrm{g}\right)$ & 2.51 & 2.44 & 2.50 \\
$\begin{array}{c}\text { Volume weight ratio } \\
\text { after tapping }\end{array}$ & $\left(\mathrm{cm}^{3} / \mathrm{g}\right)$ & 2.06 & 2.06 & 2.06 \\
$\begin{array}{c}\text { Compression ratio, } R_{\mathrm{c}} \\
(\%)\end{array}$ & 18.1 & 15.7 & 17.4 \\
$D_{\mathrm{p} 50}$ & $(\mu \mathrm{m})$ & 73 & 74 & 75 \\
\hline & $\left(c_{\mathrm{IPA}}=50 \%, T=0^{\circ} \mathrm{C}, n=28 \mathrm{rpm}\right)$
\end{tabular}

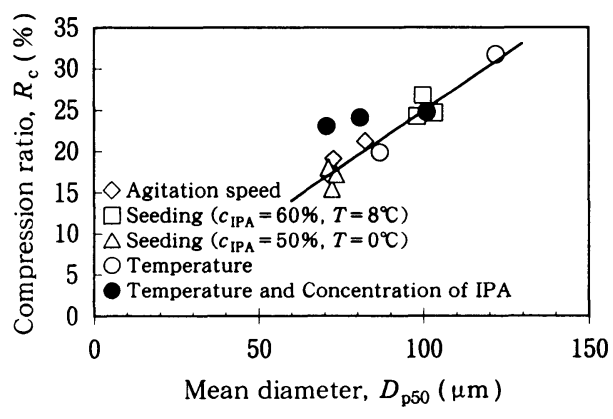

Fig. 13 Compression ratio as a function of mean diameter

き，ほぼ 1 本の直線で表される。すなわち，大きな粒 子ほど压縮率が高い粒子となっていると言える。これ は，原料量が同じであるので，粒子が大きいほど疎な 粒子となり，タッピングによる機械的な力で破壊され やすくなったためであると考えられる。機械的な力で 破壊されやすい粒子であれば比抵抗も大きくなると予 想されるが，Fig. 14 に示したように，比抵抗を圧縮 率に対してプロットすると，压縮率 21〜23\% を超え ると压縮率が高い方が比抵抗は大きくなるが，それ以 下では明確な傾向はない。このことから，压縮率を求 める時にタッピングにより結晶粒子に加わる力に比べ て, 比抵抗を求める時に流体より粒子に加わる力が小 さいため, タッピングでは粒子の破砕が起きても, 流 体による圧密では粒子の破砕が起きない場合があるこ とが考えられる。よって，ある程度緻密な凝集結晶が 生成されれば，擋拌速度の影響のように，流体による 破砕が起きず，粒子径の大小がそのまま流体透過比抵 抗に影響する場合がある。

このことは，滤過過程を模した比抵抗による評価で は，王縮率の評価のように単純な機械的特性の評価で はなく，流体透過にかかわる種々の特性の影響を含め て総合的に評価できるという利点を示す。その一方 で, 本研究で設定した予圧密圧力では比抵抗は小さく

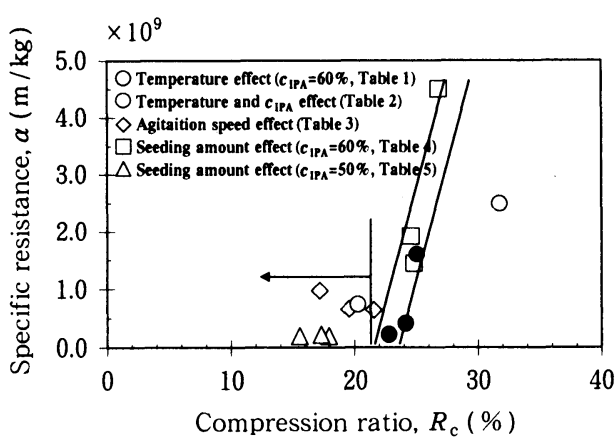

Fig. 14 Specific resistance as a function of compression ratio

ても，透過圧力を変えると評価結果が変わることも予 想される。そこで, 最も比抵抗の小さかった晶析温 度 $0^{\circ} \mathrm{C}$, IPA 濃度 $50 \%$ 之, 基準の $8^{\circ} \mathrm{C}, 60 \%$ につい て, 透過圧力を変化させてケーク比抵抗を求めた結果 をFig. 15 に示す。透過圧力に対して比抵抗は線形に 増加し, 晶析温度 $0{ }^{\circ} \mathrm{C}$, IPA 濃度 $50 \%$ の条件で得ら れた結晶のケーク比抵抗がいずれの圧力でも低い。よ って，上記の検討結果は，本研究で対象としている遠 心分離機を用いた滤過圧力においても成立すると考え られる。

\section{4 検討結果の評価と実用性の確認}

滤過性向上の確認のため, 比抵抗の検討の結果得ら れた最適操作条件 (晶析温度 $0^{\circ} \mathrm{C}$, IPA 濃度 $50 \%$ ) で の結晶粒子，および，比較対象として従来の晶析条件 で得られた結晶粒子（晶析温度 $12^{\circ} \mathrm{C}$, IPA 濃度 60 \%）を用いて，小型遠心機を用いた滤過実験を行った 結果を Table 6 に示す。この表から，最適化した条件 では滤過時間が約 $1 / 2$ に短縮されることが分かる。

一方, 最適操作条件では, 滤過後のケーク層中に含 まれる液量の指標となる Dry/Wet 質量比は最適操作 条件の方が大きくなり，一方，ケーク層の厚みは小さ

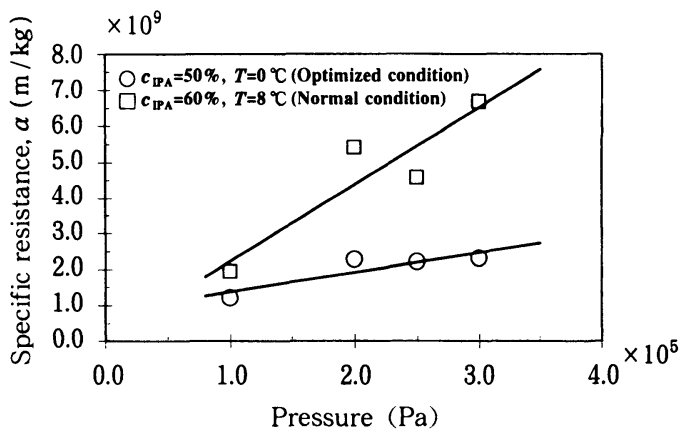

Fig. 15 Effect of filtration pressure on specific resistance 
Table 6 Results of filtration tests using centrifugal filter having $120 \mathrm{~cm}^{2}$ of filtration area

\begin{tabular}{llcc}
\hline \multicolumn{2}{c}{ Crystallization conditions } & $\begin{array}{c}c_{\text {IPA }}=60 \%, T=12^{\circ} \mathrm{C} \\
\text { (normal condition) }\end{array}$ & $\begin{array}{c}c_{\text {IPA }}=50 \%, T=00^{\circ} \mathrm{C} \\
\text { (optimized condition) }\end{array}$ \\
\hline Filtration time & $(\mathrm{s})$ & 289 & 145 \\
Dry/ Wet mass ratio & $(-)$ & 0.467 & 0.630 \\
Volume weight ratio & $\left(\mathrm{cm}^{3} / \mathrm{g}\right)$ & 3.74 & 3.18 \\
Thickness of cake & $(\mathrm{mm})$ & $27-28$ & $20-22$ \\
\hline
\end{tabular}

く, かつ, 乾燥後の結晶の比容は小さい。これらか ら, 前述の実験結果と同様, 最適操作条件では, 遠心 時の付加压力では破砕等の起こらない粒子が析出した ことが推定される。すなわち, 最適操作条件では付加 圧力での結晶粒子の破砕が起こらないが，従来の操作 条件で析出した粒子では破砕等が起こり, 比容の小さ な微小粒子で緻密なケーク層が形成されるため, 層厚 さは小さくなると考えられる。また，微小粒子のため 近隣粒子との接触点数が多くなり, 接触点近傍での液 架橋が増えたことで保液量が増えたと考えられる。

\section{4. 結 言}

Darcy の圧密透過試験から得られるケーク比抵抗 を指標に, 精 WIN 滤過性の向上について検討し, 以 下のことが明らかになった。

1) 晶析温度を低温にすると, 晶析初期の析出速度が 緩やかになり，ケーク比抵抗は小さくなる。

2 ) 擋拌速度が大きいと, タッピング法により求めた 結晶の压縮性には変化はないがケーク比抵抗も大き くなる。
3 ）晶析初期の析出速度は, 種晶量が多い, すなわ ち, 種晶の総表面積が大きい方が大きくなる。一 方, 析出速度之圧縮率, 比抵抗との間に明確な関連 は見られない。これらから, 種晶量は, 晶析温度や 回転速度のように，一次結晶の凝結過程には影響せ ず，主に，析出結晶と種晶との衝突確率に影響する と考えられる。

4) 粒子特性としてタッピング法により求めた圧縮率 が 21〜23\% を超えると，压縮率と比抵抗に相関は 見られるが，それ以下では明確な傾向はない。この ことは，滤過過程を模した比抵抗による評価では， 圧縮率の評価のように単純な機械的特性の評価では なく，流体透過にかかわる種々の特性の影響を含め て総合的に評価できるという利点を示す。

5 ) 濾過性向上の確認のため, 比抵抗の検討の結果得 られた最適操作条件での結晶粒子，および，比較対 象として従来の晶析条件で得られた結晶粒子を用い て，小型遠心機を用いた滤過実験を行った。その結 果, 最適化した条件では濾過時間が約 $1 / 2$ に短縮で きることが，確認された。

\section{Nomenclature}

C : concentration of Wincef during crystallization

$C_{0}$ : initial concentration of Wincef

$C^{*}$ : saturation concentration of Wincef

$c_{\text {IPA }}$ : volumetric concentration of isopropyl alcohol

$D$ : diameter of crystallization vessel

$d$ : diameter of agitation impeller

$D_{\mathrm{p} 50}:$ mean diameter

$\left(\mathrm{kg} / \mathrm{m}^{3}\right)$
$\left(\mathrm{kg} / \mathrm{m}^{3}\right)$
$\left(\mathrm{kg} / \mathrm{m}^{3}\right)$
$\quad(-)$
$(\mathrm{m})$
$(\mathrm{m})$
$(\mu \mathrm{m})$

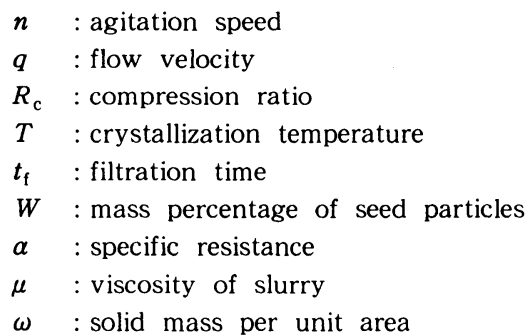

$(\mathrm{rpm})$ $(\mathrm{m} / \mathrm{s})$ $\left(\mathrm{kg} / \mathrm{m}^{2}\right)$

\section{References}

1 ) Kawashima, Y., M. Imai, H. Takeuchi, H. Yamamoto, K. Kamiya and T. Hino: "Improved Flowability and Compatibility of Spherically Agglomerated Crystals of Ascorbic Acid for Direct Tableting Designed by Spherical Crystallization Process", Powder Technol., 130, 283-
$289(2003)$

2 ) Mukuta, T. : "Process Development to Obtain Agglomerate Crystals Suitable for Powder Filling”, Kagaku Kogaku Ronbunshu, 30, 745-751 (2004) 